\title{
PENGARUH METODE PEMBELAJARAN ROLE PLAY DAN GAYA BELAJAR TERHADAP HASIL BELAJAR IPS KELAS IV SD MUHAMMADIYAH 31 HELVETIA KOTA MEDAN
}

\author{
Junaidi Amin Sitepu ${ }^{1}$, Samsidar Tanjung ${ }^{2}$ \\ Pascasarjana Universitas Negeri medan ${ }^{1,2}$ \\ Junaidi_amins@gmail.com ${ }^{l}$
}

\begin{abstract}
Abstrak: Penelitian ini bertujuan untu mengetahui: (1) hasil belajar IPS siswa yang dibelajarkan dengan menggunakan metode pemelajaran role play dan hasil belajar siswa yang dibelajarkan dengan menggunakan metode ekspositori, (2) hasil belajar siswa yang memiliki gaya belajar visual, gaya belajar auditori, dan gaya belajar kinestetik, (3) interaksi antara metode pembelajaran dengan gaya belajar dalam mempengaruhi hasil belajar IPS. Metode penelitian menggunakan metode quasi eksperimen dengan rancangan faktorial 2 X 3. Teknik analisis data menggunakan analisis varians (ANAVA) dua jalur dengan taraf signifikansi $5 \%(\alpha=0.05)$.. Hasil penelitian menunjukkan: (1) hasil belajar IPS siswa yang dibelajarkan dengan metode pembelajaran role play lebih tinggi dari hasil belajar IPS siswa yang dibelajarkan dengan metode pembelajaran ekspositori; (2) terdapat perbedaan hasil belajar antara siswa yang memiliki gaya belajar visual, gaya belajar auditori, dan gaya belajar kinesteti; (3) terdapat interaksi antara metode pembelajaran dan gaya belajar dalam meningkatkan hasil belajar IPS.
\end{abstract}

Kata Kunci: role play dan gaya belajar terhadap hasil belajar ips

Abstract: This study aims untu determine: (1) the results of social studies students that learned by using learning role play and learning outcomes of students that learned by using the expository method, (2) the learning outcomes of students who have a visual learning style, learning style auditory, and kinesthetic learning styles, (3) the interaction between the learning method with learning styles in influencing learning outcomes IPS. The research method using quasiexperimental method with factorial design $2 X 3$. Data were analyzed using analysis of variance (ANOVA) two lanes with a significance level of $5 \%(\alpha=0,05)$.. The results showed: (1) the results of social studies students that learned with learning methods play a higher role than the results of social studies students that learned with expository teaching methods; (2) there are differences in learning outcomes between students who have a visual learning style, auditory learning styles and learning styles kinesteti; (3) There is no interaction between teaching methods and learning styles to improve learning outcomes IPS.

Keywords: role play and learning style on learning outcomes ips

\section{PENDAHULUAN}

Pelajaran IPS merupakan salah satu pelajaran pokok dan penting di sekolah dasar. Sesuai dengan kurikulum pendidikan nasional bahwa setiap siswa harus dapat mencapai kriteria ketuntasan minimal, maka dalam memberikan pembelajaran IPS guru harus benar-benar dapat menyampaikan bahan ajar kepada siswa secara efektif dan dapat dipahami oleh para siswa. Kenyataan di lapangan dari hasil observasi peneliti melihat bahwa hasil belajara IPS siswa kelas IV SD Muhammadiya 31 Helvetia Medan masih banyak siswa yang hasil belajarnya belum mencapai kriteria ketuntasan minimal. Hal ini dikarenakan masih banyak siswa yang kurang memahami konsep pelajaran IPS tersebut. Dengan menggunakan metode pembelajaran dan media pembelajaran yang tepat dan sesuai dengan gaya belajar siswa diharapkan mampu meningkatkan hasil belajar IPS sesuai dengan hasil kriteria ketuntasan minimal..

Berbagai usaha perbaikan dan
penelitian mengenai cara-cara untuk meningkatkan mutu pendidikan sudah banyak dilakukan oleh para pendidik untuk meningkatkan keberhasilan studi siswa. Namun demikian, hasilnya belum banyak dinikmati oleh para guru, siswa dan orang tua yang 
diperlihatkan melalui hasil belajar siswa. Keberhasilan hasil belajar siswa ditentukan oleh banyak faktor antara lain guru, kurikulum, sarana dan prasarana, lingkungan, motivasi, administrasi dan yang dari peserta didik itu sendiri yaitu gaya belajar siswa. Hasil belajar merupakan hasil yang diperoleh melalui usaha balajar. Hasil belajar yang baik dan optimal adalah harapan yang ingin dicapai dalam setiap kegiatan belajar mengajar. Oleh karena itu, untuk meningkatkan hasil belajar di SD perlu diadakan perbaikan-perbaikan dalam bidang kurikulum, administrasi, metode mnegajar, dan sarana prasarana yang memadai.

Selama ini hasil belajar siswa SD pada mata pelajaran IPS relatif rendah dibandingkan dengan mata pelajaran sosial yang lainnya. Berdasarkan hasil observasi dan pengamatan peneliti, pembelajaran IPS di dalam kelas, guru hanya menggunakan metode ekspositori (ceramah) tanpa divariasikan dengan metode lainnya yang dapat membuat siswa tertarik dengan mata pelajaran IPS. Selain itu, dengan membuat siswa sebagai pendengar yang baik, sangat tidak menjamin kalau materi pelajaran yang diberikan kepada siswa melalui metode ceramah dapat diterima siswa.

Salah satu faktor yang berpengaruh terhadap hasil belajar siswa ada dalam diri siswa itu sendiri . Salah satu faktor yang ada di dalam diri siswa adalah gaya belajar siswa. Pengetahuan tentang bagaimana gaya belajar siswa akan memungkinkan disusunnya suatu kegiatan belajar mengajar dan suasana belajar yang sesuai dengan kebutuhan siswa. Dan ini akan membawa akibat lebih lanjut yang positif yaitu diperolehnya pola proses belajar mengajar yang lebih baik, sehingga akan meningkatkan hasil belajar. Pengetahuan akan gaya belajar siswa ini akan bermanfaat bagi guru dan pihak sekolah dalam menerapkan pembelajaran dan suasana belajar yang tepat sesuai tipe/gaya belajar siswa.

Dengan mengetahui gaya belajar siswa tersebut, guru bisa menentukan metode mengajar yang dapat digunakan untuk memberikan stimulus kepada siswa yang memiliki aneka ragam gaya belajar tersebut. Salah satu metode belajar mengajar yang dapat dipilih oleh guru dalam melaksanakan pembelajaran IPS adalah dengan mengajar menggunakan metode yang membuat siswa ikut serta dan aktif yang nantinya akan meningkatkan kemampuan siswa baik kognitif, afektif maupun psikomotorik siswa.
Metode role play/bermain peran adalah salah satu bentuk permainan pendidikan (educational games) yang dipakai untuk menjelaskan perasaan, sudut pandangan, dan cara berpikir orang lain (membayangkan diri sendiri seperti dalam keadaan orang lain). Dengan menggunakan metode role play, siswa dapat belajar sambil bermain peran. Metode ini dapat melibatkan semua siswa dan melatih kemampuan kognitif, afektif, terutama psikomotorik siswa.

IPS merupakan kajian terpadu untuk ilmu-ilmu sosial dan kemanusiaan dalam pengembangan potensi kewarganegaraan. IPS dikoordinasikan sebagai suatu bahasan yang dibangun dari beberapa disiplin ilmu seperti: Antropologi, arkeologi, ekonomi, geografi, sejarah, hukum, filsafat, ilmu politik, psikologi, agama dan sosiologi, selain itu juga mencakup materi humaniora, matematika dan ilmu alam secara sistematis.

Savage (1997: 9) mengatakan bahwa sampai saat ini belum ada satu konsensus mengenai subjek materi IPS. Tujuan IPS yang dideklarasikan National Council for Social Studies (NCSS), sebuah asosiasi pendidik yang profesional dalam bidang sosial, seringkali dipakai sebagai istilah IPS adalah sebagai berikut:

Social studies is the integrated study of the social sciences and humanities to promote civic competence. Within the school program, social studies provides coordinated, systematic study drawing upon such disciplines as anthropology, archaeology, economics, geography, history, law, philosophy, political science, psychology, religion, and sociology, as well as appropriate content from the humanities, mathematics, and natural sciences.

IPS merupakan kajian terpadu untuk ilmu-ilmu sosial dan kemanusiaan dalam pengembangan potensi kewarganegaraan. IPS dikoordinasikan sebagai suatu bahasan yang dibangun dari beberapa disiplin ilmu seperti: Antropologi, arkeologi, ekonomi, geografi, sejarah, hukum, filsafat, ilmu politik, psikologi, agama dan sosiologi, selain itu juga mencakup materi humaniora, matematika dan ilmu alam secara sistematis.

Selain itu ruang lingkup pembelajaran IPS juga dapat merujuk pada Permendiknas No. 22 tahun 2006 tentang Standar Isi yang berisis Standar Kompetensi dan Kompetensi Dasar IPS SD/MI; Ruang lingkup mata pelajaran IPS meliputi aspek-aspek sebagai berikut 
(1)Manusia, tempat dan lingkungan, (2) Waktu, keberkanjutan dan perubahan, (3) Sistem Sosial dan budaya, (4) Perilaku ekonomi dan kesejahteraan. Berdasarkan aspek-aspek yang dipelajari, maka ruang lingkup merupakan materi yang akan diberikan pada peserta didik untuk mencapai tujuan belajar.

Belajar adalah proses usaha yang dilakukan seseorang untuk memperoleh perubahan tingkah laku yang baru secara keseluruhan sebagai hasil pengalamannya sendiri dalam interaksi dengan lingkungannya (Slameto, 2003:2)

Skinner (dalam Dimyati \& Mudjiono, 2006:9) berpandangan bahwa belajar adalah suatu perilaku. Pada saat orang belajar, maka responnya menjadi lebih baik. Sebaliknya, bila ia tidak belajar maka responnya menurun. Dalam belajar ditemukan adanya hal berikut: kesempatan terjadinya peristiwa yang menimbulkan respon si pebelajar, konsekuensi yang bersifat menguatkan respon tersebut. Pemerkuat terjadi pada stimulus yang menguatkan konsekuensi tersebut.

Sejalan dengan itu, Sadiman (2001:2) mengemukakan bahwa "belajar adalah suatu rangkaian kegiatan jiwaraga, psiko-fisik, menuju ke perkembangan pribadi manusia seutuhnya yang berarti menyangkut unsur cipta, rasa dan karsa, ranah koqnitif, afektif, dan psikomotorik". Belajar merupakan kegiatan mental yang tidak dapat di saksikan dari luar. Apa yang sedang terjadi dalam diri seseorang yang sedang belajar tidak diketahui secara langsung hanya dengan mengamati orang lain. Bahkan hasil belajar orang itu tidak langsung kelihatan tanpa orang itu melakukan sesuatu menampakan kemampuan yang telah diperoleh melalui belajar.

Hasil pembelajaran menurut Reigeluth (1983) dalam Miarso (1988:15) didefinisikan sebagai semua efek yang dapat dijadikan sebagai indikator tentang nilai dari penggunaan suatu metode di bawah kondisi yang berbeda. Efek ini bisa berupa efek yang sengaja dirancang, karena ia merupakan efek yang diinginkan, dan juga berupa efek nyata sebagai hasil penggunaan metode pembelajaran tertentu.

Mengajar adalah suatu usaha yang sangat kompleks, sehingga sulit menentukan bagaimana sebenarnya mengajar yang baik. Metode adalah salah satu alat untuk mencapai tujuan. Sedangkan "pembelajaran adalah suatu kegiatan yang dilakukan oleh guru sedemikian rupa sehingga tingkah laku siswa berubah ke arah yang lebih baik" (Darsono, 2000:24). Menurut Ahmadi (1997: 52) dikutip oleh Yatik Hidayanti, metode pembelajaran adalah suatu pengetahuan tentang cara-cara mengajar yang dipergunakan oleh guru atau instruktur.

Wina Sanjaya (2008:147) menyebutkan bahwa metode adalah cara yang digunakan untuk mengimplementasikan rencana yang sudah disusun dalam kegiatan nyata agar tujuan yang telah disusun tercapai secara optimal. Sedangkan metode pembelajaran adalah cara yang digunakan oleh guru dalam melaksanakan kegiatan belajar mengajar di kelas sebagai upaya untuk mencapai tujuan pembelajaran yang telah ditetapkan sedangkan dalam buku

Pengertian lain mengatakan bahwa metode pembelajaran merupakan teknik penyajian yang dikuasai oleh guru untuk mengajar atau menyajikan bahan pelajaran kepada siswa di dalam kelas, baik secara individual ataupun secara kelompok agar pelajaran itu dapat diserap, dipahami dan dimanfaatkan oleh siswa dengan baik

\section{Role Play}

Peran (role) bisa diartikan sebagai cara seseorang berperilaku dalam posisi situasi tertentu (Gangel, 1986). Metode role playing adalah suatu cara penguasaan bahan-bahan pelajaran melalui pengembangan imajinasi dan penghayatan dilakukan siswa dengan memerankannya sebagai tokoh hidup atau benda mati.

Menurut Gangel (1986) role playing adalah suatu metode mengajar yang merupakan tindakan yang dilakukan secara sadar dan diskusi tentang peran dalam kelompok. Pandangan senada dikemukakan oleh Blatner (2002) yang menurutnya metode role playing adalah sebuah metode untuk mengeksplorasi hal-hal yang menyangkut situasi sosial yang kompleks. Di dalam kelas, suatu masalah diperagakan secara singkat sehingga muridmurid bisa mengenali tokohnya. Salah satu struktur permainan menurut Gangel (1986) adalah (1) Persiapan dengan menentukan masalah, buat persiapan peran, membangun suasana, pilihlah tokohnya, jelaskan dan berikan pemanasan, dan pertimbangkan latihan. (2) Memainkan dengan memainkan, menghentikan,

Shaftel (1967) dalam Joyce, Weil, Calhoun (2009:333) mengemukakan ada 
sembilan langkah tahapan dalam pelaksanaan role play.

Adapun langkah-langkah struktur pengajaran dalam metode role play tersebut adalah:

Tahap Pertama: Menghangatkan situasi kelas, Mengidentifikasi atau memperkenalkan masalah, Menjelaskan masalah, Menafsirkan masalah dalam cerita, dan menelusuri isu, Menjelaskan role playing

Tahap Kedua: Memilih Partisipan, Menganalisis peran, Memilih pemain peran,

Tahap Ketiga: Mensetting Pentas/tempat kejadian, Mengatur rangkaian tindakan, Merekapitulasi peran, Mendalami situasisituasi problematik.

Tahap Keempat: Menyiapkan Peneliti, Mempersiakan apa yang akan dicari, Menugaskan observasi, Tahap Kelima: Memerankan, Memulai permainan peran, Mengukuhkan permainan peran, Menghentikan permainan peran

Tahap Keenam: Diskusi dan Evaluasi, Mereview tindakan dalam role play, (peristiwa, posisi, dan realisme), Mendiskusikan fokus utama, Mengembangkan pemeranan selanjutnya.

Tahap Ketujuh: Memerankan Kembali, Memainkan peran yang telah diubah, Menyarankan langkah-langkah selanjutnya atau alternatif-alternatif prilaku.

Tahap Kedelapan: Mendiskusikan dan Mengevaluasi, Sesuai dengan tahap keenam, Tahap Kesembilan: Berbagi dan Mengembangkan Pengalaman, Menghubungkan situasi permasalahan dengan pengalaman yang sebenarnya terjadi dan masalah-masalah mutakhir, Menelusuri prinsip prilaku secara umum.

Pembelajaran ekspositori adalah pembelajaran yang menekankan kepada proses penyampaian materi secara verbal dari seorang guru kepada sekelompok siswa dengan maksud agar siswa dapat menguasai materi pelajaran secara maksimal. Metode ini merupakan bentuk pembelajaran yang berorientasi kepada guru . Dikatakan demikian karena dalam pembelajaran ini guru memegang peranan yang sangat dominan. Guru menyampaikan materi pelajaran secara berstruktur dengan harapan materi pelajaran yang disampaikan dapat dikuasai siswa dengan baik. Fokus utamanya adalah kemampuan akademik (academic achievement) (Sanjaya, 2007:179)

Slameto (2003:163) menyatakan dalam metode ekspositori, guru menyajikan materi yang harus dipelajari, memberikan jawabanjawaban, menyajika prinsip-prinsip dan mengelaborasikan seluruh isi yang harus dipelajari. Pengajaran di sini merupakan proses mengajar deduktif, dimulai dengan pemberian definisi dari konsep, prinsip-prinsip yang akan diajar, menjelaskannya dan memberitahukan implikasi-implikasinya.

Dimyati \& Mudjiono (2002:172) menyetakan bahwa dalam pembelajaran ekspositori guru aktif memberikan penjelasan atau informasi terperinci tentang bahan pengajaran. Tujuan utamanya adalah "memindahkan" pengetahuan, keterampilan dan nilai-nilai kepada siswa. Peranan guru dalam pembelajaran ini adalah ; (1) penyusunan program pembelajaran, (2) pemberi informasi yang benar, (3) pemberi fasilitas belajar yang baik, (4) pembimbing siswa dalam pemerolehan informasi yang benar dan (5) penilai pemerolehan informasi.

Suherli (2009) menyatakan bahwa metode ekspositori merupakan metode yang berusaha memberikan kejelasan sesuatu atau suatu peristiwa yang sedang dipelajari oleh siswa. Hakikat mengajar menurut metode ini merupakan penyampaian ilmu pengetahuan kepada siswa, siswa dipandang sebagai objek yang menerima apa yang diberikan guru. Umumnya guru menyampaikan informasi mengenai bahan pengajaran dalam bentuk penjelasan dan penuturan secara lisan, yang dikenal dengan istilah kuliah, ceramah, lecture. Siswa diharapkan dapat menangkap dan mengingat informasi yang diberikan oleh guru, serta mengungkap apa yang dimilikinya melalui respon yang ia berikan pada saat diberikan pertanyaann oleh guru.

Makmun (2003:233) dalam Sagala (2007:79) menyatakan bahwa guru dalam menyajikan bahan dalam bentuk yang telah dipersiapkan secara rapi, sistematik dan lengkap sehingga siswa hanya menyimak dan mencernanya secara teratur dan rapi. Pada umumnya guru lebih suka menggunakan metode ekspositori karena lebih mudah dilaksanakan dengan persiapan yang lebih sederhana, hemat waktu dan tenaga dengan satu langkah langsung bisa menjangkau semua siswa dan dapat dilakukan cukup di dalam kelas. Sagala (2007:79) menyatakan bahwa guru berperan lebih aktif, lebih banyak melakukan aktifitas daripada siswa karena guru telah mengelola dan mempersiapkan bahan ajaran hingga tuntas dan menyajikan bahan pelajaran 
secara utuh atau menyeluruh, lengkap dan sistematis dengan penyampaian secara verbal, sedangkan siswa berperan pasif tanpa banyak melakukan pengolahan bahan, karena siswa menerima bahan ajaran yang telah disampaikan oleh guru.

Komunikasi pembelajaran yang digunakan guru dalam interaksinya dengan siswa menggunakan komunikasi satu arah atau komunikasi sebagai aksi. Kegiatan siswa terbatas pada mendengarkan uraian guru, mencatat dan sekali-kali bertanya kepada guru. Kegiatan belajar yang bersifat menerima terjadi karena menempatkan guru sebagai pusat pengajaran, karena guru menjadi lebih aktif memberikan informasi, menerangkan suatu konsep, mendemontrasikan keterampilan dalam memperoleh pola, aturan, dalil, memberikan contoh soal beserta penyelesaiannya. Dalam pembelajaran ini guru berperan lebih aktif, lebih banyak melakukan aktivitas daripada siswa, guru telah mengelola dan mempersiapkan bahan ajaran secara tuntas sedangkan siswa menerima bahan ajaran yang disampaikan oleh guru (Sagala, 2007:78)

Sanjaya (2007:179) menyatakan bahwa terdapat beberapa karakteristik metode ekspositori, yaitu: (1) ekspositori dilakukan dengan cara menyampaikan materi pelajaran secara verbal, artinya bertutur secara lisan merupakan alat utama dalam melakukan strategi ini, oleh karena itu sering oleh mengidentifikasinya dengan ceramah, (2) biasanya materi pelajaran yang disampaikan adalah materi pelajaran yang sudah jadi, seperti data atau fakta, konsep-konsep tertentu yang harus dihafal sehingga tidak menuntut siswa untuk berfikir ulang, (3) tujuan utama pembelajaran adalah penguasaan materi pelajaran itu sendiri, artinya setelah proses pembelajaran berakhir siswa diharapkan dapat memahaminya dengan benar dengan cara dapat mengungkapkan kembali materi yang telah diuraikan.

Sanjaya (2007:185) menguraikan prosedur pelaksanaan metode ekspositori; (1) rumuskan tujuan yang ingin dicapai (2) kuasai materi pelajaran dengan baik, (3) kenali medan dan berbagai hal yang dapat mempengaruhi proses penyampaian.

Keberhasilan penggunaaan metode ekspositori sangat tergantung pada kemampuan guru untuk bertutur dan menyampaikan materi pelajaran. Ada beberapa langkah dalam penerapan strategi ekspositori, yaitu ; (1) persiapan; berkaitan dengan mempersiapkan siswa untuk menerima pelajaran. Tujuan yang hendak dicapai dalam melakukan persiapan adalah ; mengajak siswa keluar dari kondisi menral yang pasif, membangkitkan motivasi dan minat siswa untuk belajar, merangsang dan menggugah rasa ingin tahu siswa dan menciptakan suasana dan iklim pembelajaran yang terbuka; (2) penyajian; merupakan langkah penyampaian materi pelajaran yang sesuai dengan persiapan yang telah dilakukan. Yang harus dipikirkan seorang guru adalah bagaimana agar materi pelajaran dapat dengan mudah ditangkap dan dipahami oleh siswa; (3) korelasi; merupakan langkah menghubungkan materi pelajaran dengan pengalaman siswa atau dengan hal-hal lain yang memungkinkan siswa dapat menangkap keterkaitannya dalam struktur pengetahuan yang dimilikinya. Langkah ini dilakukan untuk memberi makna terhadap materi pelajaran; (4) menyimpulkan; merupakan tahapan untuk memahami inti (core) dari meteri yang disajikan. Dengan menyimpulkan siswa akan dapat mengambil intisari dari proses penyajian; (5) mengaplikasikan; merupakan langkah unjuk kemampuan siswa setelah mereka menyimak penjelasan guru. Melalui langkah ini guru dapat mengumpulkan informasi tentang penguasaan dan pemahaman materi pelajaran oleh siswa (Sanjaya, 2007:185-190)

Sanjaya (2007:190-192) menyatakan bahwa metode pembelajaran ekspositori merupakan metode yang banyak dan sering digunakan. Hal ini disebabkan metode ini memiliki beberapa keunggulan, diantaranya; (1) guru mengontrol urutan dan keluasan materi pembelajaran, dengan demikian ia mengetahui sejauh mana siswa menguasai bahan pelajaran yang disampaikan, (2) metode ini dianggap sangat efektif apabila materi pelajaran yang harus dikuasi siswa cukup luas dengan waktu yang dimiliki terbatas, (3) melalui metode ekspositori selain siswa dapat mendengar melalui penuturan tentang suatu materi pelajaran, juga sekaligus siswa bisa melihat atau mengobservasi, (4) keuntungan lain adalah metode ini bisa digunakan untuk jumlah siswa dan ukuran kelas yang besar.

Sanjaya (2007) juga menyatakan disamping memiliki keunggulan, metode ekspositori ini juga memiliki kelemahan, diantaranya ; (1) hanya mungkin dapat dilakukan terhadap siswa yang memiliki kemampuan mendengan dan menyimak secara 
baik, (2) tidak mungkin dapat melayani perbedaan setiap individu baik perbedaan kemampuan, perbedaan pengetahuan, minat, bakat serta gaya belajar karena penyampaian materi dilakukan secara verbal, (3) lebih banyak diberikan melalui ceramah maka akan sulit mengembangkan kemampuan siswa dalam hal kemampuan sosialisasi, hubungan interpersonal serta kemampuan berfikir kritis, (4)keberhasilan metode ini sangat tergantung kepada apa yang dimiliki guru, (5) gaya komunikasi pada yang terjadi pada metode pembelajaran ini lebih banyak terjadi pada satu arah (one way communication), maka kesempatan untuk mengontrol pemahaman siswa akan materi pembelajaran akan sangat terbatas pula, (6) sangat sulit memelihara perhatian siswa untuk tetap mendengar dan menyimak pelajaran dalam waktu yang lama.

Informasi tentang adanya gaya belajar yang berbeda-beda mempunyai pengaruh atas kurikulum, administrasi dan proses belajarmengajar. Masalah ini sangat kompleks, sulit, memakan waktu banyak, biaya yang tidak sedikit, frustasi. Tak ada satu metode yang sesuai dengan murid. Ada yang lebih serasi belajar sendiri, ada yang lebih senang menjelaskan dan informasi dari guru melalui metode ceramah dan ada juga siswa yang senang belajar secara diskusi (Nasution 2000:93).

Dalam hal ini Nasution (2000:94) menyatakan bahwa : gaya belajar adalah cara yang konsisten yang dilakukan seorang murid dalam menangkap stimulus atau informasi, cara mengingat, berfikir dan memecahkan soal. Tidak semua orang mengikuti cara yang sama, masing-masing menunjukan perbedaan, namun para ahli menggolong-golongkan gaya belajar berkaitan erat dengan pribadinya seorang yang tentu dipengaruhi oleh pendidikan riwayat perkembangannya.

Slameto (2003:160) menyatakan bahwa gaya belajar dapat dikonsepsikan sebagai sikap, pilihan, atau strategi yang stabil menentukan cara seseorang yang khas dalam menerima, mengingat, berfikir dan memecahkan masalah. Setiap siswa berbeda dalam cara memperoleh, menyimpan serta menerapkan pengetahuan.

Psikolog Widyastuti

(2003), menyatakan bahwa setiap anak memiliki cara dan kecepatan yang berbeda dalam menyerap dan mencerna informasi, biarkan anak tumbuh dan berkembang dengan polanya sendiri, asal targetnya tetap ada.
Belajar terjadi pada tiga tahap yaitu meneria informasi, memahami, dan mengerti informasi serta mengingat an memproduksi informasi. Sanjaya (2007:129) menyatakan bahwa pembelajaran pada dasarnya penambahan informasi dan kemampuan baru. Selanjutnya ditambahkan bahwa ada beberapa pertimbangan yang harus diperhatikan sebelum menentukan metode pembelajaran yang dapat digunakan, diantaranya; (1) tujuan yang akan dicapai, (2) bahan dan materi pembelajaran, (3) siswa sesuai dengan gaya belajar siswa.

Bobby DePorter, Mark Reardon, dan Sarah singer Nourie dalam Quantum Teaching (1999:84) mengungkapkan,"gaya belajar seseorang dapat dibedakan dalam gaya belajar visual, auditorial, dan kinestetik, tetapi bukan berarti seseorang harus digolongkan kedalam salah satu tipe secara permanent". Dalam kenyataannya, kita semua memiliki ketiga gaya belajar tersebut, hanya saja biasanya satu gaya mendominasi". Walaupun masing-masing dari siswa belajar dengan menggunakan ketiga gaya belajar pada tahap tertentu, kebanyakan siswa lebih cendrung pada salah satu diantara ketiganya.

De Porter (2000:112) menyatakan bahwa langkah penting untuk membantu belajar menjadi lebih cepat dan mudah adalah mengenali karakteristik dari masing-masing tipe gaya belajar tersebut. Karakteristik dari masingmasing tipe gaya belajar tersebut adalah sebagai berikut: pertama: gaya belajar tipe visual adalah gaya belajar yang dominan mengandalkan visual, belajar dengan cara melihat. Karakteristik gaya belajar visual ini adalah; (1) Rapi dan teratur, (2) Berbicara dengan cepat, (3) Perencana dan pengatur jangka panjang yang baik,(4) teliti terhadap detail, (5) mementingkan dalam penampilan, baik dalam hal pikiran maupun presentasi, (6) pengeja yang baik dan dapat melihat kata-kata yang sebenarnya dalam pikiran mereka, (7) mengingat apa yang dilihat daripada apa yang didengar, (8) mengingat dengan asosiasi visual, (9) biasanya tidak terganggu oleh keributan, (10) mempunyai masalah untuk mengingat instruksi verbal kecuali jika ditulis, dan seringkali minta bantuan orang untuk mengulanginya, (11) pembaca cepat dan tekun, (12) lebih suka membaca daripada dibacakan, (13) membutuhkan pandangan dan tujuan yang menyeluruh dan bersikap waspada sebelum secara mental secara pasti tentang suatu masalah atau proyek, (14) mencoret-coret tanpa 
arti selama berbicara ditelefon dan alam rapat, (15) lupa menyampaikan pesan verbal kepada orang lain, (16) sering menjawab pertanyaan dengan jawaban singkat ya atau tidak, (17) lebih suka melakukan demonstrasi daripada berpidato, (18) lebih suka seni daripada music, (19) seringkali mengetahui apa yang harus dikatakan tetapi tidak sepandai dalam memilih kata-kata, (20) kadang-kadang kehilangan konsentrasi ketika mereka ingin memperhatikan.

Hipotesis yang diajukan dalam penelitian ini adalah: (1) Siswa yang diajar dengan metode role play memperoleh hasil belajar yang lebih tinggi dari siswa yang diajar dengan metode ekspository (ceramah); (2) Ada perbedaan hasil belajar antara siswa yang memiliki gaya belajar visual, auditori, dan kinestetik; dan (3) Ada interaksi antara metode pembelajaran dan gaya belajar terhadap hasil belajar IPS siswa.

\section{METODE}

Penelitian ini dilaksanakan di SD Muhammadiyah 31 Kecamatan Medan Helvetia Kota Medan, Sumatera Utara. Populasi penelitian ini adalah siswa SD Muhammadiyah 31 Helvetia Medan yang duduk dikelas IV. Jumlah populasi seluruhnya adalah 91 orang yang terdiri dari 3 kelas yaitu kelas IV A, IV B, dan IV C. Subjek diambil secara acak sejumlah 60 orang, yaitu 1 kelas IV A 30 orang sebagai kelas eksperimen yang dibelajarkan dengan metode pembelajaran role play dan 1 kelas IV B 30 orang sebagai kelas kontrol yang dibelajarkan dengan metode pembelajaran ekspositori. Teknik pengambilan sample yang digunakan adalah cluster random sampling.

Jenis penelitian ini adalah penelitian kuantitatif eksperimen semu (quasiexperimental research) dengan rancangan faktorial 2X3. Kuasi eksperimen merupakan sebuah eksperimen semu dalam sebuah penelitian karena melibatkan penggunaan kelompok subjek utuh dalam eksperimen yang secara alami sudah terbentuk dalam kelas daripada menentukan subjek secara random untuk perlakuan eksperimen (Wiersma, 1995). Melalui rancangan ini dibandingkan pengaruh penggunaan metode pembelajaran role play dan metode pembelajaran ekspositori terhadap hasil belajar IPS yang ditinjau dari gaya belajar siswa. Metode pembelajaran role play dan metode pembelajaran ekspositori sebagai variable bebas, gaya belajar sebagai variable moderator, dan hasil belajar IPS sebagai variable terikat yang kemudian dimasukkan di dalam rancangan penelitian pada Tabel 1 berikut.

Tabel 1. Desain Penelitian

\begin{tabular}{|l|c|c|}
\hline \multirow{2}{*}{ Metode Pembelajaran } & \multicolumn{2}{|c|}{ Metode Pembelajaran (A) } \\
\cline { 2 - 3 } Gaya Belajar $(\mathbf{B})$ & $\begin{array}{c}\text { Pembelajaran IPS dengan } \\
\text { Metode Role Play } \\
\left(\mathbf{A}_{1}\right)\end{array}$ & $\begin{array}{c}\text { Pembelajaran IPS } \\
\text { Dengan Metode Ekspositori } \\
\left(\mathbf{A}_{2}\right)\end{array}$ \\
\hline $\begin{array}{l}\text { Siswa dengan gaya belajar } \\
\text { visual (B })\end{array}$ & $\mathrm{A}_{1} \mathrm{~B}_{1}$ & $\mathrm{~A}_{2} \mathrm{~B}_{2}$ \\
\hline $\begin{array}{l}\text { Siswa dengan gaya belajar } \\
\text { Auditorial }\left(\mathrm{B}_{2}\right)\end{array}$ & $\mathrm{A}_{1} \mathrm{~B}_{2}$ & $\mathrm{~A}_{2} \mathrm{~B}_{2}$ \\
\hline $\begin{array}{l}\text { Siswa dengan gaya belajar } \\
\text { Kinestetik }\left(\mathrm{B}_{3}\right)\end{array}$ & $\mathrm{A}_{1} \mathrm{~B} 3$ & $\mathrm{~A}_{2} \mathrm{~B}_{3}$ \\
\hline
\end{tabular}

\section{Keterangan :}

$\mathrm{A}_{1} \mathrm{~B}_{1}$ : Hasil belajar IPS siswa dengan gaya belajar visual yang diajarkan dengan metode role play

$\mathrm{A}_{1} \mathrm{~B}_{2}$ : Hasil belajar IPS siswa dengan gaya belajar auditorial yang diajarkan dengan metode role play

$A_{1} B_{3}$ : Hasil belajar IPS siswa dengan gaya belajar kinestetik yang diajarkan dengan metode role play
$A_{2} B_{1}$ : Hasil belajar IPS siswa dengan gaya belajar visual yang diajarkan dengan menggunakan metode ekspositori

$\mathrm{A}_{2} \mathrm{~B}_{2}$ : Hasil belajar IPS siswa dengan gaya belajar auditorial yang diajarkan dengan menggunakan metode ekspositori

$A_{2} B_{3}$ : Hasil belajar IPS siswa dengan gaya belajar kinestetik yang diajarkan dengan menggunakan metode ekspositori

Statistik deskriptif digunakan untuk menyajikan data yang telah diperoleh melalui 
wawancara, angket dalam bentuk tabel (distribusi frekuensi, ukuran pemusatan, ukuran letak, dan ukuran keragaman), gambar diagram maupun grafik sehingga mudah dipahami. Untuk angket atau kuisioner yang telah diisi dicari skor-skor keseluruhan responden dalam satu kelas dan simpangan bakunya. Kategorisasi hasil pengukuran menggunakan distribusi normal (Mardapi, 2008: 122-123). Tingkat kecenderungan di bagi dalam empat kategori. Kategori tersebut dapat dilihat pada Tabel 2 berikut.

Tabel 2. Kriteria penilaian masing-masing variabel

\begin{tabular}{|c|c|c|}
\hline No & Rentang Skor & Kategori \\
\hline 1 & $\mathrm{X} \geq \bar{X}+1 . \mathrm{SBx}$ & Sangat Tinggi \\
\hline 2 & $\mathrm{X}+1 . \mathrm{SBx}>\mathrm{X} \geq \bar{X}$ & Tinggi \\
\hline 4 & $\mathrm{X}>\bar{X} \geq \mathrm{X}-1 . \mathrm{SBx}$ & Kurang \\
\hline 5 & $\mathrm{X}<\bar{X}-1 . \mathrm{SBx}$ & Sangat Kurang \\
\hline
\end{tabular}

Keterangan:

$\bar{X}=$ Rerata skor keseluruhan siswa dalam satu kelas

$\mathrm{SBx}=$ Simpangan Baku

$\mathrm{X}=$ Skor yang dicapai siswa

Interval kategori variabel tersebut

didasarkan pada skor tertinggi dan skor terendah dari masing-masing variabel penelitian. Selanjutnya dicari skor rerata ideal $\mathrm{X}$ dan simpangan bakui deal (SBx) dengan menggunakan formula sebagai berikut.

$\mathrm{X}=1 / 2$ (skor tertinggi + skor terendah

$\mathrm{SBx}=1 / 6$ ( skor tertinggi - skor terendah)

Skor tertinggi ideal adalah skor tertinggi yang mungkin diperoleh subjek penelitian dari keseluruhan alternatif jawaban. Skor terendah ideal adalah skor yang terendah yang mungkin diperoleh subjek penelitian dari keseluruhan alternatif jawaban.

Uji prasarat analisis dilakukan yang dilakukan adalah uji normalitas, uji homogenitas, dan uji linearitas data. Uji normalitas dilakukan untuk mengetahui normal atau tidaknya sebaran data yang akan dianalisis, uji homogenitas untuk memastikan kelompok data berasal dari populasi yang homogen. Uji normalitas data menggunakan uji Liliefors, uji homogenitas menggunakan uji $F$ dan uji Bartlet.

Teknik analisis data yang digunakan untuk pengujian hipoteis adalah dengan teknik analisis varians (ANAVA) dua jalur. Dasar pemikiran teknik ANAVA adalah variansi total semua subjek dalam suatu eksperimen dapat dianalisis menjadi dua sumber varians antar kelompok dan dan varians dalam kelompok. Anava dua jalur dapat digunakan untuk menguji perbedaan duan mean atau lebih.

Penelitian ini menguji antara dua kelompok dengan perlakuan dua jenis metode pembelajaran. Disamping itu, kedua kelompok siswa dibedakan antara siswa yang diajarkan dengan menggunakan variasi metode dengan siswa yang diajarkan dengan metode konvensional dan di klasifikasikan berdasarkan gaya belajar siswa. Melalui teknik ANAVA dua jalur dalam penelitian ini diharapkan dapat menemukan perbedaan hasil belajar IPS yang diajarkan dengan menggunakan metode role play dengan yang diajarkan dengan metode ekspositori.

Adapun hipotesis statistik yang diuji dalam penelitian ini adalah:

a. Hipotesis pertama

$\mathrm{H}_{\mathrm{o}}: \mu \mathrm{A}_{1=\mu \mathrm{A}_{2}}$

$\mathrm{H}_{\mathrm{a}}: \mu \mathrm{A}_{1}>\mu \mathrm{A}_{2}$

b. Hipotesis kedua

$\mathrm{H}_{\mathrm{o}} \quad: \mu \mathrm{B}_{1}=\mu \mathrm{B}_{2}=\mu \mathrm{B}_{3}$

$\mathrm{H}_{\mathrm{a}} \quad$ : Paling sedikit ada 1 rata-rata yang berbeda

c.Hipotesis ketiga

$\mathrm{H}_{\mathrm{o}} \quad: \mathrm{A}><\mathrm{B}=0$

$\mathrm{H}_{\mathrm{a}} \quad: \mathrm{A}><\mathrm{B} \neq 0$

Keterangan :

$\mu \mathrm{A}_{1}$ : hasil belajar yang diperoleh dengan metode pembelajaran role play

$\mu \mathrm{A}_{2}$ : hasil belajar yang diperoleh dengan metode pembelajaran ekspositori

$\mu \mathrm{B}_{1}$ : hasil belajar siswa dengan gaya belajar visual

$\mu B_{2}$ : hasil belajar siswa dengan gaya belajar auditorial

$\mu \mathrm{B}_{3}$ : hasil belajar siswa dengan gaya belajar kinestetik

Kesimpulan apakah Ho diterima atau ditolak, diperoleh dengan menginterpretasikan nilai signifikan pada tabel Test of BetweenSubject Effects dari hasil analisis kovarian (ANAVA) melalui SPSS 15 for windows. Jika nilai sig. $<0,05$ maka Ho ditolak dan $\mathrm{H}_{1}$ 
diterima. Begitu juga sebaliknya, jika nilai sig. $>0,05$ maka Ho diterima dan Ha ditolak.

\section{HASIL DAN PEMBAHASAN Hasil}

Pengujian hipotesisi penelitian dilakukan dengan menggunakan teknik analisis varians (ANAVA) 2 X 3. Untuk keperluan analisis varians, perhitungan selengkapnya ada pada lampiran penelitian ini, ringkasan hasil anava dua jalur untuk pengujian hipotesis dapat dilihat pada Tabel 3 .

Tabel 3. Tabel Rangkuman Anava 2 X 3

\begin{tabular}{|c|c|c|c|c|c|}
\hline \multicolumn{3}{|c|}{ Sumber Variasi } & $\mathrm{JK}$ & $\mathrm{dk}$ & $\mathrm{RJ}$ \\
\hline \multicolumn{3}{|c|}{ Metode Pembelajaran } & 256.27 & 1 & 2 \\
\hline \multicolumn{3}{|c|}{ Gaya Belajar } & 804.12 & 2 & 4 \\
\hline \multicolumn{3}{|c|}{ Interaksi } & 331.41 & 2 & 16 \\
\hline \multicolumn{3}{|c|}{ Galat } & 2091.94 & 54 & 38 \\
\hline Total & 3483.73 & 60 & & & \\
\hline
\end{tabular}

Untuk menguji apakah berbeda hasil belajar IPS Siswa yang dibelajarkan dengan menggunakan metode pembelajaran role play dibandingkan dengan hasil belajar IPS siswa dengan menggunakan metode ekspositori, maka digunakan teknik analisis varians (ANAVA). Pengujian dilakukan pada hipotesis statistik:

$\mathrm{H}_{0}: \mu \mathrm{A}_{1=}=\mathrm{A}_{2}$

$\mathrm{H}_{\mathrm{a}}: \mu \mathrm{A}_{1}>\mu \mathrm{A}_{2}$

Atau hipotesis yang menyatakan bahwa:

$\mathrm{H}_{0}$ : Hasil belajar IPS siswa yang dibelajarkan dengan menggunakan metode role play sama dengan hasil belajar IPS siswa yang dibelajarkan dengan menggunakan metode ekspositori.

$\mathrm{H}_{\mathrm{a}}$ : Hasil belajar IPS siswa yang dibelajarkan dengan menggunakan metode pembelajaran role play lebih tinggi dari pada hasil belajar IPS siswa yang dibelajarkan dengan menggunakan metode ekspositori.

Kriteria pengujian $\mathrm{F}_{\text {hitung }}>\mathrm{F}_{\text {tabel }}$ menunjukkan bahwa hipotesis nol $\left(\mathrm{H}_{0}\right)$ ditolak dan hipotesis alternatif $\left(\mathrm{H}_{\mathrm{a}}\right)$ diterima. Dari perhitungan dengan ANAVA pada tabel 4.16 diperoleh bahwa $F_{\text {hitung antar kolom }}=10.378>\mathrm{F}_{\text {tabel }}$ $=4.02$ (untuk $\alpha=0.05$ ). Ini berarti hipotesis penelitian yang menyatakan bahwa hasil belajar IPS siswa yang dibelajarkan dengan menggunakan Metode pembelajaran role play lebih tinggi dari pada hasil belajar IPS siswa yang dibelajarkan dengan menggunakan metode ekspositori teruji kebenarannya.

Berdasarkan data hasil belajar yang diperoleh juga menunjukkan bahwa nilai ratarata hasil belajar IPS yang dibelajarkan dengan menggunakan metode pembelajaran role play (39.19), lebih tinggi dari pada nilai rata-rata

\begin{tabular}{|l|l|l|l|}
\hline JK & $F_{\text {hitung }}$ & Ftabel 5\% & F tabel 1\% \\
\hline 56.267 & 10.378 & 4.02 & \\
\hline 62.060 & 6.615 & & \\
\hline 65.703 & 4.277 & & \\
\hline 8.740 & & & \\
\hline
\end{tabular}

hasil belajar IPS siswa yang dibelajarkan dengan menggunakan metode pembelajaran ekspositori (37.48). Dari hasil perbandingan nilai rata-rata dan hasil pengujian ANAVA yang diperoleh dapat disimpulkan bahwa hasil belajar IPS siswa yang dibelajarkan dengan menggunakan metode pembelajaran role play lebih tinggi dari pada hasil belajar IPS siswa yang dibelajarkan dengan menggunakan metode pembelajaran ekspositori.

Pengujian untuk mengetahui apakah ada perbedaan hasil belajar IPS siswa antara siswa yang memiliki gaya belajar visual, gaya belajar auditori, dan gaya belajar kinestetik digunakan teknik analisis varians (ANAVA). Pengujian dilakukan pada hipotesis statistik:

$\mathrm{H}_{0}: \mu \mathrm{B}_{1}=\mu \mathrm{B}_{2}=\mu \mathrm{B}_{3}$

$\mathrm{H}_{\mathrm{a}}$ : Paling sedikit ada 2 rata-rata yang berbeda

$\mathrm{H}_{0}$ : Hasil belajar IPS siswa sama antara siswa yang memiliki gaya belajar visual, gaya belajar auditori, dan gaya belajar kinestetik.

$\mathrm{H}_{\mathrm{a}}$ : Hasil belajar IPS siswa berbeda antara siswa yang memiliki gaya belajar visual, gaya belajar auditori, dan gaya belajar kinestetik.

Kriteria pengujian $F_{\text {hitung }}>F_{\text {tabel }}$ menunjukkan hipotesis nol $\left(\mathrm{H}_{0}\right)$ ditolak dan hipotesis alternatif $\left(\mathrm{H}_{\mathrm{a}}\right)$ diterima. Dari perhitungan dengan ANAVA pada tabel 4.16 menunjukkan bahwa $\mathrm{F}_{\text {hitung }}=6.615>\mathrm{F}_{\text {tabel }}=4.02$ (untuk $\alpha=0.05$ ) sehingga hasil belajar IPS siswa antara siswa yang memiliki gaya belajar visual, gaya belajar auditori, dan gaya belajar kinestetik menunjukkan perbedaan yang signifikan terhadap hasil belajar IPS siswa. Ini berarti $\mathrm{F}_{\text {hitung }}>\mathrm{F}_{\text {tabel }}$ menunjukkan hipotesis nol $\left(\mathrm{H}_{0}\right)$ ditolak dan hipotesis alternatif $\left(\mathrm{H}_{\mathrm{a}}\right)$ diterima, dapat disimpulkan bahwa hasil belajar IPS siswa berbeda antara yang memiliki gaya belajar visual dengan siswa yang memiliki gaya 
belajar auditori dan kinestetik teruji kebenarannya. Ini menunjukkan bahwa setiap gaya belajar tidak sama hasil belajarnya untuk pelajaran IPS. Nilai rata-rata hasil belajar IPS siswa yang memiliki gaya belajar visual (40.19), nilai rata-rata hasil belajar IPS siswa yang memiliki gaya belajar auditori (35.44), nilai rata-rata hasil belajar IPS siswa yang memiliki gaya belajar kinestetik (39.38).

Untuk menguji dan mengetahui apakah ada interaksi antara metode pembelajaran dan gaya belajar dalam meningkatkan hasil belajar IPS digunakan teknik analisis varians (ANAVA). Pengujian dilakukan pada hipotesis statistik:

$$
\begin{aligned}
& \mathrm{H}_{0}: A><B=0 \\
& \mathrm{H}_{\mathrm{a}}: \mathrm{A}><\mathrm{B} \neq 0
\end{aligned}
$$

Atau hipotesis yang menyatakan bahwa:
$\mathrm{H}_{0}$ : Tidak terdapat interaksi anatara metode pembelajaran dan gaya belajar.

$\mathrm{H}_{\mathrm{a}}$ : Terdapat interaksi antara metode pembelajaran dan gaya belajar.

Kriteria pengujian $\mathrm{F}_{\text {hitung }}>\mathrm{F}_{\text {tabel }}$ menunjukkan hipotesis nol $\left(\mathrm{H}_{0}\right)$ ditolak dan hipotesis alternatif $\left(\mathrm{H}_{\mathrm{a}}\right)$ diterima. Dari perhitungan dengan ANAVA pada tabel 4.16 diperoleh bahwa $F_{\text {hitung interaksi }}=4.277 .>F_{\text {tabel }}$ $=4.02$ (untuk $\alpha=0.05$ ) sehingga menunjukkan hipotesis nol $\left(\mathrm{H}_{0}\right)$ ditolak dan hipotesis alternatif $\left(\mathrm{H}_{\mathrm{a}}\right)$ diterima, yang berarti terdapat interaksi antara metode pembelajaran dan gaya belajar siswa dalam meningkatkan hasil belajar IPS. Dengan demikian hipotesis penelitian yang menyatakan terdapat interaksi antara metode pembelajaran dan gaya belajar teruji kebenarannya.

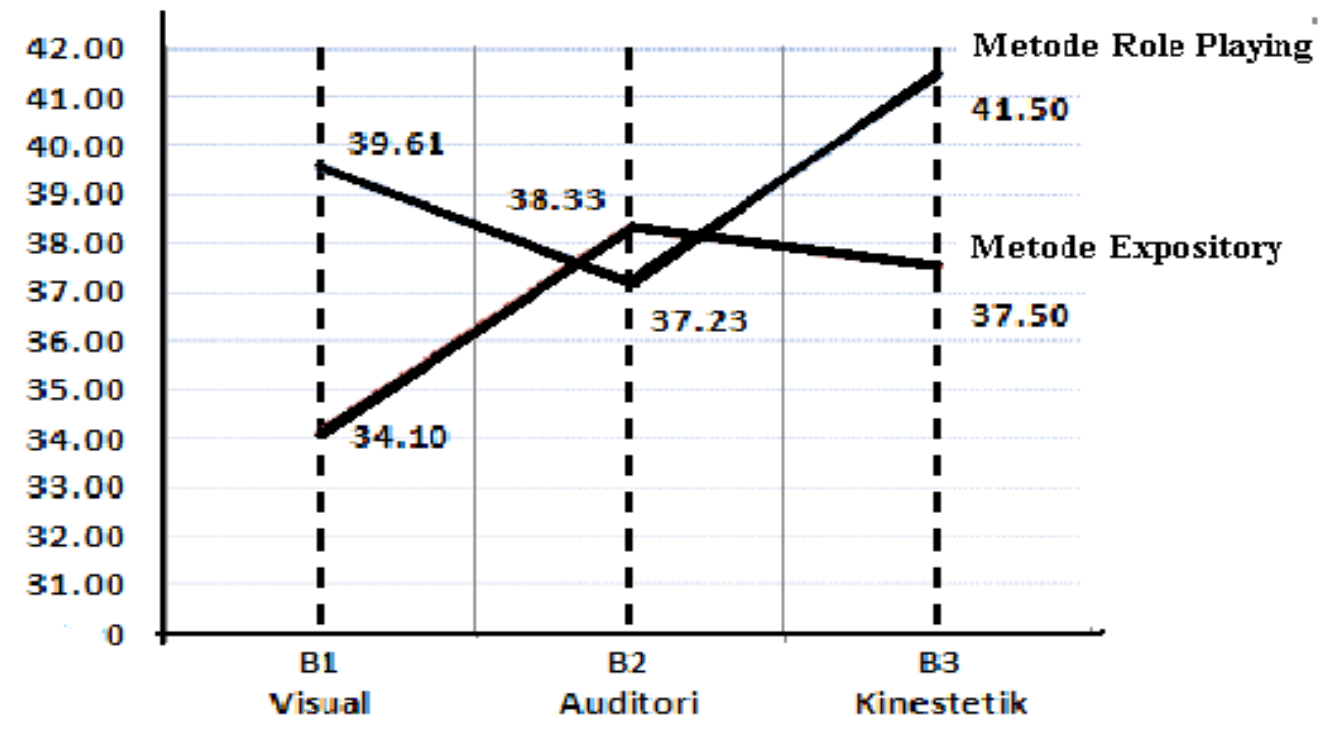

Dengan adanya interaksi antara metode pembelajaran dan gaya belajar dalam mempengaruhi hasil belajar IPS siswa, maka dilakukan uji lanjut dengan menggunakan uji sceffe. Kriteria pengujian jika $F_{\text {hitung }}>F_{\text {tabel }}$ pada $\alpha=0.05$ menunjukkan terdapat perbedaan yang signifikan. Hasil perhitungan uji lanjut dapat dilihat pada tabel 4.

Tabel 4. Ringkasan Hasil Perhitungan Uji Lanjut dengan Uji Sceffe

\begin{tabular}{|c|l|l|l|r|r|r|r|l|}
\hline No & Pasangan Hipotesis & $\bar{X}_{i}$ & $\bar{X}_{\mathrm{j}}$ & \multicolumn{1}{c|}{ ni } & nj & (F hitung) & F Tabel & \\
\hline 1 & $\mu \mathrm{A} 1 \mathrm{~B} 1 \mathrm{dan} \mu \mathrm{A} 2 \mathrm{~B} 1$ & 38.89 & 41.50 & 9 & 10 & 1.512 & 2.38 & tidak signifikan \\
\hline 2 & $\mu \mathrm{A} 1 \mathrm{~B} 1$ dan $\mu \mathrm{A} 2 \mathrm{~B} 2$ & 38.89 & 33.70 & 9 & 12 & 3.543 & 2.38 & Signifikan \\
\hline 3 & $\mu \mathrm{A} 1 \mathrm{~B} 1$ dan $\mu \mathrm{A} 2 \mathrm{~B} 3$ & 38.89 & 37.25 & 9 & 8 & 0.759 & 2.38 & tidak signifikan \\
\hline 4 & $\mu \mathrm{A} 1 \mathrm{~B} 1$ dan $\mu \mathrm{A} 1 \mathrm{~B} 3$ & 38.89 & 41.50 & 9 & 10 & 1.512 & 2.38 & tidak signifikan \\
\hline 5 & $\mu \mathrm{A} 1 \mathrm{~B} 1$ dan $\mu \mathrm{A} 1 \mathrm{~B} 2$ & 38.89 & 37.18 & 9 & 11 & 1.080 & 2.38 & tidak signifikan \\
\hline 6 & $\mu \mathrm{A} 2 \mathrm{~B} 1$ dan $\mu \mathrm{A} 2 \mathrm{~B} 2$ & 38.89 & 33.70 & 10 & 12 & 3.985 & 2.38 & Signifikan \\
\hline 7 & $\mu \mathrm{A} 2 \mathrm{~B} 1$ dan $\mu \mathrm{A} 2 \mathrm{~B} 3$ & 37.18 & 37.25 & 10 & 8 & 0.035 & 2.38 & tidak signifikan \\
\hline 8 & $\mu \mathrm{A} 2 \mathrm{~B} 1$ dan $\mu \mathrm{A} 1 \mathrm{~B} 3$ & 37.18 & 41.50 & 10 & 10 & 2.787 & 2.38 & Signifikan \\
\hline 9 & $\mu \mathrm{A} 2 \mathrm{~B} 1$ dan $\mu \mathrm{A} 1 \mathrm{~B} 2$ & 37.18 & 37.18 & 10 & 11 & 0.000 & 2.38 & tidak signifikan \\
\hline
\end{tabular}




\begin{tabular}{|l|l|r|r|r|r|r|r|l|}
\hline 10 & $\mu \mathrm{A} 2 \mathrm{~B} 2$ dan $\mu \mathrm{A} 2 \mathrm{~B} 3$ & 33.70 & 37.25 & 12 & 8 & 2.111 & 2.38 & tidak signifikan \\
\hline 11 & $\mu \mathrm{A} 2 \mathrm{~B} 2$ dan $\mu \mathrm{A} 1 \mathrm{~B} 3$ & 33.70 & 41.50 & 12 & 10 & 5.990 & 2.38 & Signifikan \\
\hline 12 & $\mu \mathrm{A} 2 \mathrm{~B} 2$ dan $\mu \mathrm{A} 1 \mathrm{~B} 2$ & 33.70 & 37.18 & 12 & 11 & 2.960 & 2.38 & Signifikan \\
\hline 13 & $\mu \mathrm{A} 2 \mathrm{~B} 3$ dan $\mu \mathrm{A} 1 \mathrm{~B} 3$ & 37.25 & 41.50 & 8 & 10 & 2.167 & 2.38 & tidak signifikan \\
\hline 14 & $\mu \mathrm{A} 2 \mathrm{~B} 3$ dan $\mu \mathrm{A} 1 \mathrm{~B} 2$ & 37.25 & 37.18 & 8 & 11 & 0.038 & 2.38 & tidak signifikan \\
\hline 15 & $\mu \mathrm{A} 1 \mathrm{~B} 3$ dan $\mu \mathrm{A} 1 \mathrm{~B} 2$ & 41.50 & 37.18 & 10 & 11 & 3.058 & 2.38 & Signifikan \\
\hline
\end{tabular}

\section{Pembahasan}

Berdasarkan hasil perhitungan statistik pada penelitian ini yang diperoleh adalah hasil belajar IPS siswa yang dibelajarkan dengan menggunakan metode role play lebih tinggi dibandingkan dengan hasil belajar IPS siswa yang dibelajarkan dengan menggunakan metode ekspositori, kemungkinan hal ini dikarenakan metode pembelajaran role play yang menuntut siswa lebih berperan aktif. Siswa dapat memerankan dirinya sesuai dengan apa yang ada dalam pembelajaran baik itu sebagai tokoh hidup ataupun memerankan sebagai benda mati. Dengan demikian siswa sebagai pusat perhatian dan memiliki kebebasan untuk mengekspresikan dirinya. Pembelajaran juga berlangsung didasarkan pada karakteristik masing-masing siswa yang beragam dan memerlukan kebebasan. Dalam proses pembelajaran dengan menggunakan metode pembelajaran role play, keterlibatan siswa secara aktif dapat memacu dan memunculkan kreatifitas dan imajinasi siswa itu sendiri sehingga siswa dengan mudah dapat menerima dan menguasai bahan-bahan pelajaran melalui pemeranan dan penghayatan. Hal ini didukung oleh Gangel (1986) yang menyatakan bahwa role playing adalah suatu metode mengajar yang merupakan tindakan yang dilakukan secara sadar dan diskusi tentang p0eran dalam kelompok. Hal senada juga di kemukakan oleh Blatner (2002) yang menurutnya bahwa metode role play adalah sebuah metode untuk mengeksplorasi hal-hal yang menyangkut situasi sosial yang kompleks.

Pembelajaran dengan menggunakan metode pembelajaran role play teruji kebenarannya atau diyakini keunggulannya dalam meningkatkan hasil belajar IPS siswa. Dengan kata lain siswa pada saat proses pembelajaran tidak akan bosan dan jenuh karena hanya mendengarkan guru berceramah dalam menyampaikan bahan ajar. Siswa berperan aktif dan bebas untuk berimajinasi dan mengekspresikan dirinya dalam proses pembelajaran. Guru hanya sebagai pengamat dan fasilitator bagi para siswanya. Metode pembelajaran role play juga dapat memberikan pengalaman baru bagi siswa yang selama ini terikat dan terbiasa hanya mendengarkan guru berceramah dalam menyampaikan bahan ajarnya. Pembelajaran yang berpusat hanya pada guru dan guru sebagai sumber pesan dan sumber utama dalam belajar menjadikan pembelajaran menjadi membosankan karena siswa hanya sebagai penerima pesan dan pendengar yang baik. Dengan Metode pembelajaran role play siswa dapat lebih aktif dalam belajar dan menyelesaikan permasalahan-permasalahan dalam belajar, keterlibatan siswa memacu kretivitas dan imajinasinya.

Dari hasil penelitian yang diperoleh memberikan simpulan bahwa hasil belajar IPS siswa yang dibelajarkan dengan metode pembelajaran role play lebih tinggi dari hasil belajar IPS siswa yang dibelajarkan dengan metode ekspositori. Hal ini sesuai dengan dugaan sebelumnya yang mengunggulkan metode pembelajaran role play dalam pembelajaran IPS. Keunggulan metode pembelajaran role play yang dipaparkan pada kerangka berfikir terbukti empiris dilapangan, sehingga ini menguatkan bahwa metode pembelajaran role play hasil belajar IPS lebih baik.

Siswa yang memiliki gaya belajar kinestetik, suka belajar melalui gerakan dan interaksi kelompok, paling baik menerima dan mengingat informasi dengan mengasosiasikan gerakan dengan setiap fakta. Siswa dengan gaya belajar kinestetik lebih menyukai pembelajaran terapan.

Setiap siswa memiliki cara yang disukainya sesuai dengan gaya belajar yang dimilikinya dalam menerima dan menyerap apa yang dilihat, diingat, dan difikirkannya. Gaya belajar juga mempengaruhi prestasi belajar siswa pada mata pelajaran-mata pelajaran tertentu. Semua gaya belajar sama baiknya, sebab masing-masing gaya belajar memiliki kekuatan sendiri-sendiri. Siswa dengan gaya belajar visual menekankan pada penglihatan, siswa dengan gaya belajar auditori menekankan 
pada pendengaran, sedangkan siswa dengan gaya belajar kinestetik melalui gerakan dan interaksi kelompok.

Hal ini juga sesuai dengan apa yang dinyatakan oleh nasution (2000:94) bahwa gaya belajar adalah cara yang konsisten yang dilakukan seorang siswa dalam menangkap stimulus atau informasi, cara mengingat, berfikir, dan memecahkan permasalahan. Pernyataan yang serupa juga dinyatakan oleh slameto (2003:160) bahwa gaya belajar dapat dikonsepsikan sebagai sikap, pilihan, atau strategi yang stabil menentukan cara seseorang yang khas dalam menerima, mengingat, berfikir, dan memecahkan masalah. Setiap siswa berbeda dalam cara memperoleh, menyimpan, serta menerapkan pengetahuan.

Pembelajaran IPS mengkaji tentang ilmu-ilmu sosial yang berkaitan erat dengan kehidupan sosial manusia, sehingga IPS merupakan pengetahuan yang menggambarkan, melukiskan, dan mendeskrispsikan dan menerapkan hal-hal yang berkaitan dengan kehidupan sosial manusia sehari-hari. Dalam pembelajaran IPS, guru tidak hanya menyampaikan metari secara lisan saja, tetapi harus juga dibantu dengan media pembelajaran yang dapat dilihat langsung dan dapat diterapkan dalam kehidupan sosial masyarakat sehari-hari. Hal ini tentunya membutuhkan media visual seperti kaset video, poster-poster dan buku-buka yang dapat memperlihatkan langsung objek. Selain itu juga pembelajaran IPS harus dapat dipraktekkan dalam langsung didalam kelas baik itu secara individu maupun kelompok agar nantinya dapat diterapkan langsung dalam kehiduapan sosial masyarakat.

Dari hasil uji hipotesis yang dilakukan dalam penelitian ini, dimana $F_{\text {hitung }}>F_{\text {tabel. }}$ Hal ini menunjukkan bahwa ada perbedaan hasil belajar siswa antara siswa yang memiliki gaya belajar visual, gaya belajar auditori, dan gaya belajar kinestetik.

Setiap siswa belajar menurut caranya sendiri dan setiap guru juga memiliki cara dan metode mengajar sendiri juga. Kesesuaian gaya mengajar dengan gaya belajar siswa akan mempertinggi efektifitas belajar. De Porter (2000:112) menyatakan bahwa langkah penting untuk membantu belajar menjadi lebih cepat dan lebih mudah adalah dengan gaya belajarnya. Oleh karena itu sangat penting bagi seorang guru untuk dapat mengetahui gaya belajar tiap-tiap siswanya agar dapat menentukan metode pembelajaran apa yang paling tepat digunakan dalam pembelajaran. Dari hasil penelitian menunjukkan bahwa metode pembelajaran dan gaya belajar saling berinteraksi dalam meningkatkan hasil belajar IPS. Dapat dilihat bahwa $F_{\text {hitunginteraksi }}=4.277>$ $\mathrm{F}_{\text {tabel }}=4.02$ (untuk $\alpha=0.05$ ) sehingga terdapat interaksi antara metode pembelajaran dan gaya belajardalam meningkatkan hasil belajar IPS.

Hasil yang diperoleh melalui uji lanjut dengan menggunakan uji Sceffe adalah:

1. Hasil belajar IPS siswa yang dibelajarkan dengan menggunakan metode pembelajaran role play menunjukkan bahwa siswa yang memiliki gaya belajar kinestetik lebih unggul dibandingkan dengan siswa yang memiliki gaya belajar auditori dan visual. Nilai rata-rata siswa yang memiliki gaya belajar visual $=39.61$, siswa yang memiliki gaya belajar auditori = 37.23, dan siswa yang memiliki gaya belajar kinestetik $=41.50 . \mathrm{F}_{\text {hitung }}$ antara $\mathrm{A}_{1} \mathrm{~B}_{1}$ dengan $\mathrm{A}_{1} \mathrm{~B}_{2}=1.080<\mathrm{F}_{\text {tabel }}=2.38$ pada $\alpha=0.05, \mathrm{~F}_{\text {hitung }}$ $\mathrm{A}_{1} \mathrm{~B}_{1}$ dengan $\mathrm{A}_{1} \mathrm{~B}_{3}=1.512<\mathrm{F}_{\text {tabel }}=2.38$ pada $\alpha=0.05, \mathrm{~F}_{\text {hitung }} \mathrm{A}_{1} \mathrm{~B}_{2}$ dengan $\mathrm{A}_{1} \mathrm{~B}_{3}=3.058>$ $\mathrm{F}_{\text {tabel }}=2.38$ pada $\alpha=0.05$. Ini menunjukkan bahwa hasil belajar IPS siswa yang memiliki gaya belajar kinestetik lebih unggul dibandingkan dengan gaya belajar visual dan auditori dengan menggunakan metode pembelajaran role play.

2. Hasil belajar IPS siswa yang dibelajarkan dengan metode pembelajaran ekspositori menunjukkan bahwa siswa yang memiliki gaya belajar auditori lebih unggul dari pada siswa yang memiliki gaya belajar visual dan kinestetik. Nilai rata-rata siswa yang memiliki gaya belajar visual $=34.10$, siswa yang memiliki gaya belajar auditori $=38.33$, dan siswa yang memiliki gaya belajar kinestetik = 37.50. $F_{\text {hitung antara }} \mathrm{A}_{2} \mathrm{~B}_{1}$ dengan $\mathrm{A}_{2} \mathrm{~B}_{2}=3.985$ $>\mathrm{F}_{\text {tabel }}=2.38$ pada $\alpha=0.05, \mathrm{~F}_{\text {hitung }} \mathrm{A}_{2} \mathrm{~B}_{1}$ dengan $\mathrm{A}_{2} \mathrm{~B}_{3}=0.035<\mathrm{F}_{\text {tabel }}=2.38$ pada $\alpha=0.05$, $\mathrm{F}_{\text {hitung }} \mathrm{A}_{2} \mathrm{~B}_{2}$ dengan $\mathrm{A}_{2} \mathrm{~B}_{3}=2.111<\mathrm{F}_{\text {tabel }}=2.38$ pada $\alpha=0.05$. Ini berarti hasil belajar IPS siswa yang memiliki gaya belajar auditori lebih unggul dengan menggunakan metode pembelajaran ekspositori.

\section{PENUTUP}

Berdasarkan hasil penelitian dan pembahasan yang telah diuraikan pada bab sebelumnya, maka dapat disimpulkan sebagai berikut:

1. Hasil belajar IPS siswa kelas IV SD Muhammadiyah 31 Helvetia Kota Medan yang dibelajarkan dengan metode 
pebelajaran role play lebih tinggi dibandingkan dengan hasil belajar IPS siswa yang dibelajarkan dengan ekspositori.

2. Terdapat perbedaan hasil belajar IPS siswa kelas IV SD Muhamadiyah 31 Helvetia Kota Medan antara siswa yang memiliki gaya belajar visual, gaya belajar auditori, dan gaya belajar kinestetik.

3. Terdapat interaksi antara metode pembelajaran dan gaya belajar dalam mempengaruhi hasil belajar IPS siswa kelas IVSD Muhammadiyah 31 Helvetia Kota Medan. Siswa yang memiliki gaya belajar kinestetik dan visual lebih efektif bila menggunakan metode pembelajaran role play, sedangkan siswa yang memiliki gaya belajar auditori lebih efektif jika dibelajarkan dengan metode ekspositori.

\section{DAFTAR PUSTAKA}

Allen, M. J., \& Yen, W. M. (1979). Introduction to measurement theory. California: Wadsworth, Inc.

Baharuddin \& Esa Nur (2008). Teori Belajar dan Pembelajaran. Joyjakarta: AR-Ruzz Media

Cholid Narbuko \& H. Abu Achmadi. (2007). Metodologi Penelitian. Jakarta: Bumi Aksara.

Conny R. Semiawan. (2008). Belajar dan Pembelajaran Prasekolah dan Sekolah Dasar. Jakarta: PT. Macanan Jaya Cemerlang.

De Porter, Bobbi, Mark Randon, Saras SinearVorie (2000). Quantum Teaching (terjemahan dari Ari Nilandari). Bandung: Kaifa
Djamarah,S.B (2002) Psikologi Belajar. Jakarta: PT. Rieneka Cipta

Ellis, Arthur K. (1997). Teaching and Learning in Elementary Social Studies (sixth edition): USA, Seattle Pasific University

Jarolimek, John. (1986). Social Studies in Elementary Education, seventh edition. New York: Macmillan Publishing Co.

Nasution, S (2003). Berbagai pendekatan dalam proses belajar mengajar. Jakarta: PT. Bina Aksara

Oemar Hamalik. (2001). Kurikulum dan pembelajaran. Bandung: Penerbit Alumni

Peraturan Menteri No. 22 (2006). Standar kompetensi dan kompetensi dasar SD/MI). Jakarta: BSNP Depdiknas.

Sadiman, A.M. (2001). Interaksi dan Motivasi Belajar Mengajar. Jakarta: PT. Raja Grafindo Persada

Samples, Bob (2002). Revolusi belajar untuk anak. Bandung: Kaifa

Savage, Tom V. \& Amstrong, David G. (1997). Teaching in Elementary Social Studies (third edition). Prentice Hall.

Sugiyono. (2006). Statistik untuk penelitian. Bandung: Alfabeta.

Suharsimi Arikunto. (2001). Dasar-dasar evaluasi pendidikan. Jakarta: Bumi Aksara.

Sumarna Surapranata. (2006). Analisis, validitas, reliabilitas dan interpretasi hasil tes: implementasi kurikulum 2004. Bandung: Remaja Rosdakarya.

Usman,U. (2001). Menjadi Guru Profesional. Bandung: PT. Remaja Rosdakarya 